\title{
Original
}

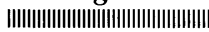

\section{Exposure Doses of Interventional Cardiologist during Intracoronary Radiotherapy with Phosphorus-32}

\author{
Atsushi FukUdA, Keitaro KitabayashI, Yoshiharu Iwadate and Ichiro YAMAgUCHI* \\ Department of Radiology, Shiga Medical Center for Adults \\ 5-4-30 Moriyama, Moriyama-shi, Shiga Pref. 524-8524, Japan \\ * Department of Environmental Health, National Institute of Public Health \\ 4-6-1 Shirokane-Dai, Minato-ku, Tokyo 108-8638, Japan \\ Received January 14, 2003
}

\begin{abstract}
Background: In our center, clinical trial with ${ }^{32} \mathrm{P}$ began in June 2001. This new medical treatment method is expected to be a promising cure with few side effects. To establish the validity of a new treatment method, it is necessary to evaluate the efficacy of treatment and secure the safety of interventional cardiologists. This study evaluates the exposure dose of the interventional cardiologists during intracoronary radiotherapy with ${ }^{32} \mathrm{P}(5.5 \mathrm{GBq})$.

Method: We measured the amount of beta ray irradiation using a rate of $\mathrm{H}^{\prime}\left(0.07,0^{\circ}\right)$, detained in the centering catheter. Then, we measured braking radiation dose using $\mathrm{H}^{\prime}\left(10,0^{\circ}\right)$ of ${ }^{32} \mathrm{P}$, with the original phantom.

Results : Exposure dose of interventional cardiologists during this new treatment was $2.0 \mu \mathrm{Sv} /$ procedure as an effective dose. The radiation dose at the intracoronary radiotherapy is relatively less compared with conventional $X$-ray medical radiation techniques. However, the interventional cardiologist is exposed mainly when a radioactive source is outside of a patient $\left[\mathrm{H}^{\prime}\left(10,0^{\circ}\right): 1.0 \mu \mathrm{Sv}\right.$ and $\left.\mathrm{H}^{\prime}\left(0.07,0^{\circ}\right): 100 \mu \mathrm{Sv}\right]$.

Conclusion: They should take a distance from a source or protect beta ray during the transit of ${ }^{32} \mathrm{P}$ from SDU (source delivery unit) to patient and return to SDU after therapy.
\end{abstract}

Key Words : phosphorus-32, intracoronary radiotherapy, coronary artery disease, beta ray, interventional cardiologist, exposure dose

\section{Introduction}

The technology of percutaneous coronary intervention(PCI) has advanced dramatically in recent years. Of particular note is that the stent technique has decreased the rate of restenosis after treatment. However, in-stent restenosis, which is diagnosed at coronary angiography, still occurs in approximately $35 \sim 40$ $\%$ of cases $^{1)}$. Intracoronary radiotherapy, a promising treatment with few side effects ${ }^{2), 3)}$, has been implemented in the catheterization laboratory following the enforcement of the new Medical Service Law in Japan from April 2001. In our center, clinical trial using intracoronary radiotherapy system (Galileo), an afterloading formula for the coronary artery made by Guidant Vascular Intervention, began in June 2001. Galileo is equipped with Phosphorus-32 $\left.{ }^{32} \mathrm{P}: 20 \mathrm{~mm}\right)$. The radioactivity of the seed was $5.5 \mathrm{GBq}(150 \mathrm{mCi})$ on receipt. We experienced 44 cases with 49 lesions by March 2002 in this clinical trial. To establish the validity of a new treatment method, it is necessary to evaluate the efficacy of treatment and secure the safety of interventional cardiologists. 
The exposure dose of interventional cardiologists performing intracoronary radiotherapy has been unclear except during radiotherapy using ${ }^{192} \operatorname{Ir}^{4}$ ). The present study was designed to estimate the exposure dose of interventional cardiologists during intracoronary radiotherapy with ${ }^{32} \mathrm{P}$ and to seek the protective way for interventional cardiologists. We measured the amount of beta ray irradiation using a rate of directional dose equivalent at depth $0.07 \mathrm{~mm}$, on a radius having direction $0^{\circ}\left[\mathrm{H}^{\prime}\left(0.07,0^{\circ}\right)\right]$ of ${ }^{32} \mathrm{P}$, detained in the catheter and the braking radiation dose using a rate of directional dose equivalent at depth $10 \mathrm{~mm}$, on a radius having direction $0^{\circ}\left[\mathrm{H}^{\prime}\left(10,0^{\circ}\right)\right]$ with the original phantom.

\section{Methods and Materials}

\section{$2 \cdot 1$ Clinical}

This study was conducted independently from the Galileo clinical trial sponsored by Guidant Vascular Intervention. The objective of the clinical trial is to assess the safety and effectiveness of localized radiation therapy using ${ }^{32} \mathrm{P}$ following $\mathrm{PCI}$ in patients with in-stent restenotic lesions. The Multicenter Review Board approved our participation. Under this protocol, patients are carefully screened for eligibility and can only be enrolled after giving fully informed consent.

After completing coronary angioplasty (i.e. plain old balloon angioplasty (POBA), directional coronary atherectomy (DCA), etc), the cardiologists measure dilations of the coronary artery's lumen at proximal and distal reference segments by intravascular ultrasound. Then the radiological technician sets up equipment to provide $20 \mathrm{~Gy}$ absorbed dose at $1 \mathrm{~mm}$ depth of the artery wall. After this setting, the cardiologist places the intracoronary radiother- apy catheter (centering catheter), without a radioactive source, at the required location in the coronary artery. The catheter position is fluoroscopically verified. The cardiologist inflates the spiral balloon of the centering catheter point with physiological saline. A non-radioactive dummy wire is advanced into the centering catheter to determine the proposed wire length. In direct patient observation, the cardiologist pushes the button to transit the radioactive wire automatically. The radioactive wire is withdrawn to the source delivery unit (SDU) automatically after it has irradiated the intended dose. After the centering catheter has been removed from the patient, the radiological technician monitors the radiation levels around the patient, this catheter, and in the catheterization laboratory to assure that all sources have been withdrawn.

\section{$2 \cdot 2$ Survey meter measurements}

We performed survey meter measurements with a phantom in the catheterization laboratory to estimate interventional cardiologist's exposure dose. The survey was conducted using an ionizing chamber instrument (A Model 450 B Victoreen Ion Chamber). We measured the interventional cardiologist' s exposure dose at 3 different phases of this therapeutic procedure (Fig. 1) . That is, during transit out of a patient's body (Phase : A), during transit within a patient's body (Phase:B), and during performance of intracoronary radiotherapy (Phase:C). Interventional cardiologists are mainly exposed to the beta ray at phase: A. Once the ${ }^{32} \mathrm{P}$ has entered the body, braking radiation irradiates them. We measured the amount of beta ray irradiation using a rate of $\mathrm{H}^{\prime}\left(0.07,0^{\circ}\right)$ of ${ }^{32} \mathrm{P}$, detained in the catheter. Then, we measured the braking radiation dose 


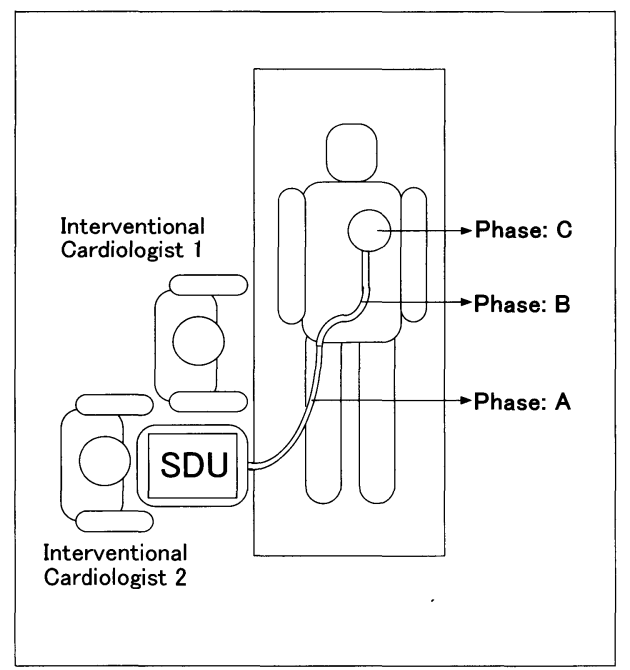

Fig. 1 Position of interventional cardiologists under intracoronary radiotherapy. This treatment is separated 3 different phases, during transit out of a patient (A), during transit within a patient (B), under intracoronary radiotherapy (C).

using a rate of $\mathrm{H}^{\prime}\left(10,0^{\circ}\right)$ with the original phantom. This phantom is MIX-DP with an inner diameter of $5 \mathrm{~mm}$. The thickness of this phantom is $2 \mathrm{~cm}$ to the thin directions, and 12.5 $\mathrm{cm}$ to thick directions.

\section{$2 \cdot 2 \cdot 1 \quad$ Phase : A}

A centering catheter was used in the actual radiotherapy. However, since the safeguard does not allow a radioactive source to stop in the middle of the centering catheter in this study, we could not measure the amount of beta ray in the work area directly. Instead we measured radiation doses from the naked state source and the source in the physics coupler to estimate the radiation dose around the centering catheter. Since the material and diameter of the inner and outer of the physics coupler and centering catheter is not exhibited, the shield capability of the centering catheter is seemed to be less than that of the physics cou- pler. In this study, we presumed that the centering catheter has half shield capability compared with the physics coupler. Regarding the medical worker's position, the survey meter and radioactive source were set from 25 to 200 $\mathrm{cm}$ apart. A Model $450 \mathrm{~B}$ Victoreen ion chamber survey meter was used. This survey meter has a $349 \mathrm{cc}$ volume air ionization chamber, which has phenolic chamber wall $246 \mathrm{mg} / \mathrm{cm}^{2}$ thick. The chamber window is $1.7 \mathrm{mg} / \mathrm{cm}^{2}$ Mylar. To measure the rate of $\mathrm{H}^{\prime}\left(0.07,0^{\circ}\right)$, we opened the window of the ion chamber using calibration coefficients provided by Battelle Company. To measure the rate of $\mathrm{H}^{\prime}\left(10,0^{\circ}\right)$, we closed its window. The calibration coefficients for beta ray particles of ${ }^{32} \mathrm{P}$ are acquired from standard ${ }^{201} \mathrm{Tl}$ and ${ }^{90} \mathrm{Sr} /{ }^{90} \mathrm{Y}$, and the coefficient for photon is acquired from ${ }^{137} \mathrm{Cs}$. The accuracy of the ion chamber is within $20 \%$ according to the calibration data.

\section{$2 \cdot 2 \cdot 2$ Phases : B, C}

A centering catheter was wholly inserted into the hole in the MIX-DP with an inner diameter of $5 \mathrm{~mm}$. Braking radiation was measured in both the thick $(12.5 \mathrm{~cm})$ and thin directions $(2 \mathrm{~cm})$ of the original body phantom. The distances of the survey meter and radioactive source were set from 25 to $200 \mathrm{~cm}$. To measure the rate of $H^{\prime}\left(10,0^{\circ}\right)$, we closed the window of the ion chamber using calibration coefficient provided by Battelle Company. The accuracy of the ion chamber is within $20 \%$ according to the calibration data. We didn' $t$ examine the exposure dose in phase: $\mathrm{B}$, because the exposure dose rate in phase : $\mathrm{C}$ is high compared with in phase: $B$, and the transit time for phase: $B$ is very short (approximately 7 seconds), and standard deviation of dwell time in phase : $\mathrm{C}$ is very long (standard deviation of 12 patient's dwell time we experienced at first was about 182 sec- 
onds).

$2 \cdot 2 \cdot 3$ The influence of the patient's physique on the exposure dose of the interventional cardiologists and the effect of a lead apron of $0.25 \mathrm{mmPb}$ equivalent

Considering variation of patient's chest wall thickness, the acrylics thickness was changed from $5 \mathrm{~mm}$ to $225 \mathrm{~mm}$ to measure the rate of $\mathrm{H}^{\prime}\left(10,0^{\circ}\right)$. Then, a lead apron of $0.25 \mathrm{mmPb}$ equivalent was arranged in front of the detector, and measurement was made in a similar manner. In addition, the energy spectrum of the braking radiation passed from the acrylics $(1 \mathrm{~cm}$ and $10 \mathrm{~cm}$ ) was measured using a NaI spectrometer (SS- $\gamma$ C 3475, Hamamatsu Photonics). The effect of a lead apron was verified. Next, the effect of this protector against scattering dose for conventional radiography was investigated. In this examination, we measured $\mathrm{H}^{\prime}\left(10,0^{\circ}\right)$ at $1 \mathrm{~m}$ from the center of the body phantom (Magen Phantom BMU-1 : Kyoto Kagaku) during P-A fluorography.

\section{$2 \cdot 3$ The patient's physique measurement}

The patient's physique was presumed using the tomogram obtained by X-ray computed tomography at the left ventricular array of 50 people (mean age was 63 years old with standard deviation of 13 years and man-woman ratio was $28: 22$ ) who consulted this center during this clinical trial period. We assumed that the radiotherapy position of ${ }^{32} \mathrm{P}$ is on the left side of the heart for safe side estimation. The measured distances are below : transverse diameter from a ${ }^{32} \mathrm{P}$ source to the left chest wall (A), transverse diameter of the left lung at the level of a ${ }^{32} \mathrm{P}$ source (B), transverse diameter from a ${ }^{32} \mathrm{P}$ source to the right chest wall (C), and transverse diameter of the right lung at

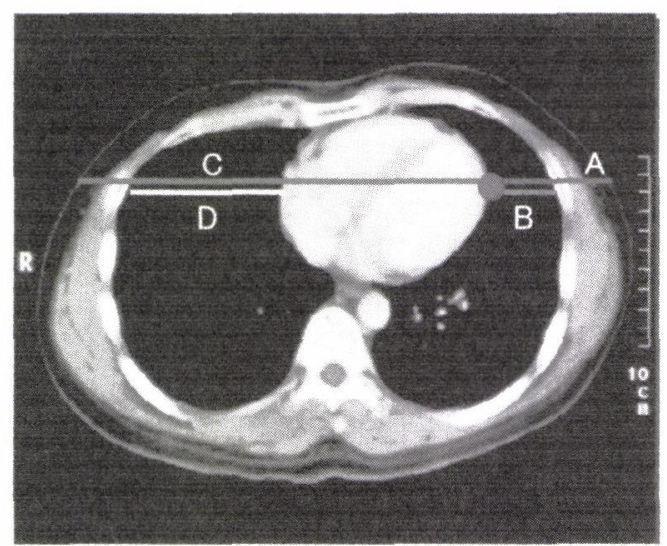

Fig. 2 Measurement of the patient physique using CT image. The small circle indicates the position of P-32 source. The measured distances are below: transverse diameter from a ${ }^{32} \mathrm{P}$ source to the left chest wall (A), transverse diameter of the left lung at the level of $\mathrm{a}^{32} \mathrm{P}$ source (B), transverse diameter from a ${ }^{32} \mathrm{P}$ source to the right chest wall (C), and transverse diameter of the right lung at the level of a ${ }^{32} \mathrm{P}$ source (D).

the level of a ${ }^{32} \mathrm{P}$ source (D) (Fig. 2).

\section{$2 \cdot 4$ Monte Carlo calculations}

In this report, the measured data were compared with those calculated with the EGS 4 Monte Carlo code ${ }^{5}$. In these simulations, the thickness of personnel was set at $25 \mathrm{~cm}$ and multislab geometry was adopted as the interventional cardiologist. The energy spectrum of electrons from ${ }^{32} \mathrm{P}$ was derived from ICRU report $56^{6)}$ (Appendix D). The absorbed doses were calculated at $0.06 \sim 0.08 \mathrm{~mm}$ from the surface of a phantom as of $\mathrm{H}^{\prime}\left(0.07,0^{\circ}\right)$ and at $0.5 \sim$ $1.5 \mathrm{~cm}$ as of $\mathrm{H}^{\prime}\left(0.07,0^{\circ}\right)$. The patient's heart was considered equivalent to water and the ${ }^{32} \mathrm{P}$ wire existed at the boundary between heart and lung. The patient's lung was considered equivalent to air and lung thickness was $4 \mathrm{~cm}$. Chest wall thickness was equivalent to water and the thickness was $2 \mathrm{~cm}$. The distance from 


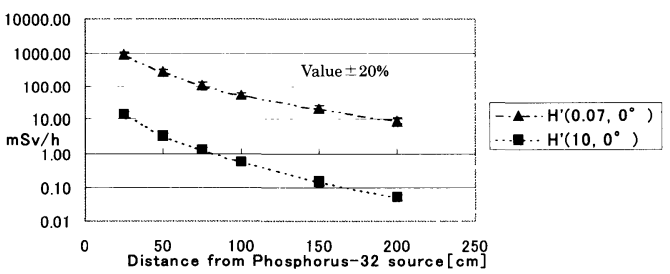

Fig. 3 Relation between distance from ${ }^{32} \mathrm{P}$ source $(5.5 \mathrm{GBq})$ in a centering catheter and ambient dose $\left[\mathrm{H}^{\prime}\left(0.07,0^{\circ}\right), \mathrm{H}^{\prime}\left(10,0^{\circ}\right)\right]$ in phase : A.

the source to the protector was set at $10 \mathrm{~cm}$. Moreover, the shielding effect of the acryl board against beta ray was calculated.

\section{Results}

$3 \cdot 1$ Survey meter measurements in phases : A, C

The measured dose rates $\left[\mathrm{H}^{\prime}\left(0.07,0^{\circ}\right), \mathrm{H}^{\prime}\right.$ $\left.\left(10,0^{\circ}\right)\right]$ taken in phase : A are shown in Fig. 3. The measured dose rates were converted into the amount of radioactivity at the time of delivery $(5.5 \mathrm{GBq})$. The rate of $\mathrm{H}^{\prime}\left(0.07,0^{\circ}\right)$ at $1 \mathrm{~m}$ from source at $5.5 \mathrm{GBq}$, was $67 \mathrm{mSv} / \mathrm{h}$ in the naked state, and $41 \mathrm{mSv} / \mathrm{h}$ within the physics coupler. Similarly at $5.5 \mathrm{GBq}$, the rate of H' (10, $0^{\circ}$ ) in the same position was $1.0 \mathrm{mSv} / \mathrm{h}$ in the naked state, and $0.1 \mathrm{mSv} / \mathrm{h}$ within the physics coupler. Consequently, $\mathrm{H}^{\prime}\left(0.07,0^{\circ}\right)$ was presumed for the centering catheter at $54.0 \mathrm{mSv} / \mathrm{h}$ when the amount of radioactivity was $5.5 \mathrm{GBq}$, because we presumed that the centering catheter had half shield capability compared with the physics coupler. The rate of $\mathrm{H}^{\prime}\left(10,0^{\circ}\right)$ was similarly presumed to be $0.6 \mathrm{mSv} / \mathrm{h}$. Fig. 4 shows results measured in phase: $\mathrm{C}$. In the thin direction $(2 \mathrm{~cm})$, the rate of $\mathrm{H}^{\prime}\left(10,0^{\circ}\right)$ at 1 $\mathrm{m}$ from source was $5.7 \mu \mathrm{Sv} / \mathrm{h}$ at the time of delivery. Whereas in the thick direction $(12.5 \mathrm{~cm})$, dose rate was $1.9 \mu \mathrm{Sv} / \mathrm{h}$ at the same time.

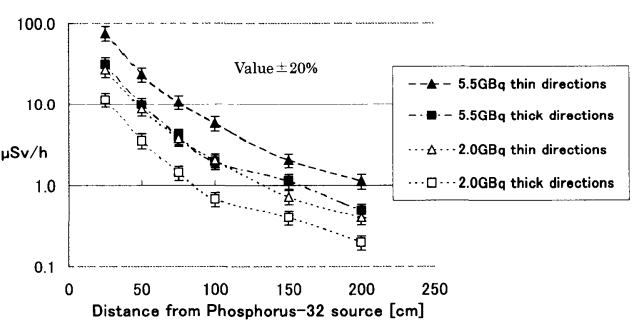

Fig. 4 Relation between distance from ${ }^{32} \mathrm{P}$ source in the MIX-DP hole and ambient dose [H' $\left.\left(10,0^{\circ}\right)\right]$ in phase: $C$. Braking radiation was measured in both the thick $(12.5 \mathrm{~cm})$ and thin $(2 \mathrm{~cm})$ of the original body phantom.

$3 \cdot 2$ The influence of the patient' $\mathrm{s}$ physique on the exposure dose of the interventional cardiologist and the shielding effect of a lead apron of $0.25 \mathrm{mmPb}$ equivalent

The relation of a patient's body size and dose rate of braking radiation is shown in Fig. 5. Dose equivalent rate decreased exponentially as the thickness of acrylics increased. Moreover, with the lead apron of $0.25 \mathrm{mmPb}$ equivalent, the dose equivalent rate decreased by half. The energy spectrum of the braking radiation passed from the acrylics $(1 \mathrm{~cm}$ and $10 \mathrm{~cm})$ was measured. During the energy distribution of braking radiation, less than $300 \mathrm{keV}$ occupied $97 \%$ as photon numbers. Even if converted into energy, $90 \%$ were occupied with the photon less than $300 \mathrm{keV}$.

\section{$3 \cdot 3$ Patient's physique analysis}

Results are shown as follows (Average length \pm S. D.). (A) was $5.9 \pm 1.9 \mathrm{~cm}$. (B) was $3.6 \pm 1.9$ $\mathrm{cm}$. (C) was $21.4 \pm 2.3 \mathrm{~cm}$. (D) was $8.0 \pm 2.0 \mathrm{~cm}$. Consequently, the estimated average patient's chest wall thickness was $2.3 \mathrm{~cm}$, and the distance from a source to a right chest wall was $13.4 \mathrm{~cm}$. Consequently, at average patient's physique and maximum radioactivity, the dose 


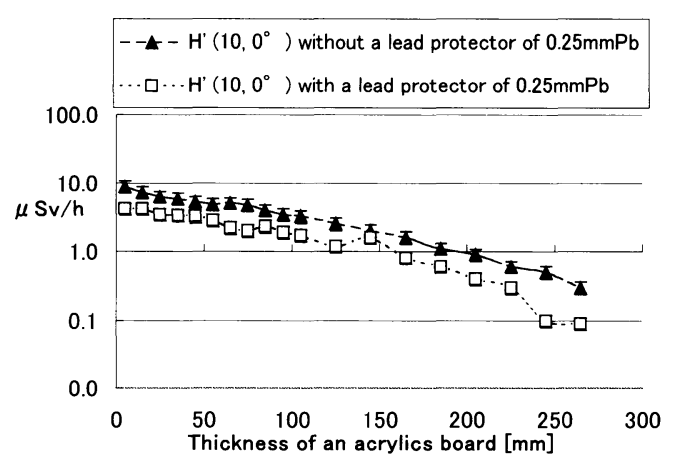

Fig. 5 Relation between thickness of an acrylics board and ambient dose $\left[\mathrm{H}^{\prime}\left(10,0^{\circ}\right)\right]$. Braking radiation from ${ }^{32} \mathrm{P}$ source in the MIX-DP hole were measured while the thickness of acrylics board was changed from $5 \mathrm{~mm}$ to $225 \mathrm{~mm}$. Then, a lead apron of $0.25 \mathrm{mmPb}$ equivalent was arranged in front of the detector, and measurement was made in a similar manner.

rate of braking radiation was presumed to be $7.5 \mu \mathrm{Sv} / \mathrm{h}$ at $1 \mathrm{~m}$ on the left side. Similarly, it was presumed to be $2.0 \mu \mathrm{Sv} / \mathrm{h}$ on the right side.

$3 \cdot 4$ The shielding effect of a $0.25 \mathrm{mmPb}$ lead protector for braking radiation on EGS 4 simulation

The result indicated that a $0.25 \mathrm{mmPb}$ lead protector for halting radiation to a patient's body reduced the exposure dose [H' $\left.\left(10,0^{\circ}\right)\right]$ to about $67.1 \%$. The number of photons at the surface of the interventional cardiologist, for which energy was at $150 \mathrm{keV}$, decreased to about $38.9 \%$, and less than $250 \mathrm{keV}$ decreased to about $52.9 \%$. Conversely, the number of photons whose energy was greater than $250 \mathrm{keV}$ increased slightly. However, this scarcely contributed to the increase in the cardiologist's exposure dose.

Whereas, an acryl board $(5 \mathrm{~mm})$ could reduce about $99.98 \%$ of the interventional cardiologist's skin absorbed dose, and the absorbed dose of deep body did not increase.

\section{Discussion}

$4 \cdot 1$ The aspects of clinical exposure dose In clinical trials using a gamma ray source, all staff other than the radiation oncologist and brachytherapy physicist leave the catheterization laboratory ${ }^{4}$. However, in clinical trials using a beta ray source, since beta rays can easily be shielded and the dose rate of braking radiation is relatively low, medical staffs are able to stay near the patient during treatment. Under this medical treatment, since the beta ray emitted from ${ }^{32} \mathrm{P}$ is not completely shielded by the centering catheter, a comparatively high dose rate is irradiated in the catheterization laboratory while the source moves between SDU and the inguinal area. At $1 \mathrm{~m}$ from the radioactive source, the rate of $\mathrm{H}^{\prime}\left(0.07,0^{\circ}\right)$ and $\mathrm{H}^{\prime}\left(10,0^{\circ}\right)$ was $100 \mathrm{mSv} / \mathrm{h}: 1 \mathrm{mSv} / \mathrm{h}$. Conversely, since the maximum pass of a beta ray in a body is 10 $\mathrm{mm}$ or less, only the braking radiation is set as the control objective after the source enters the patient's body. In phase: A, the ambient dose rate when the source moved outside the patient's body was relatively high compared with the conventional medical radiation work environment. Exposure time is only 7 seconds, so that the equivalent dose of an interventional cardiologist is $100 \mu \mathrm{Sv}$ as $\mathrm{H}^{\prime}\left(0.07,0^{\circ}\right)$ at the maximum amount of radioactivity. On the other hand, the dose from braking radiation was about $1.0 \mu \mathrm{Sv}$ in the same position when dwell time was 500 seconds as average irradiation time in clinical. This is lower than the conventional medical radiation procedure. In our facility, the dose rate at $1 \mathrm{~m}$ from a patient is around $1 \mathrm{mSv} / \mathrm{h}$ without protector and 0.1 $\mathrm{mSv} / \mathrm{h}$ with a lead apron of $0.25 \mathrm{mmPb}$ equivalence at P-A fluoroscopy. We conclude that the exposure dose at the intracoronary radiother- 
apy ( ${ }^{32} \mathrm{P}$ in the body) is relatively less compared with conventional $\mathrm{X}$-ray medical radiation techniques.

\subsection{An available methods for radiation pro-} tection in phase : A

If the beta ray shield is strengthened before the radioactive source enters the patient, safer radiotherapy is possible. However, thickening the catheter is unsuitable for some delicate operations. Although reducing the exposure dose using protective material like pipe is also considered, the centering catheter has to stay clean throughout the operation. Because of this, it may be useful to prepare radiation protective material such as a clean and flexible pipe. However these materials must be sufficiently light because a centering catheter must not be bent, or they must be applied in a manner that does not add weight to the centering catheter. We couldn't find these materials. However, since the mean free pass of beta rays in air is shorter than gamma rays, increasing the distance decreases the exposure dose. The exposure dose is weakened to about $1 / 6$ at a dose of $1 \mathrm{~m}$ by increasing the distance to $2 \mathrm{~m}$. Based on the above examination, the staff of this center move away from a source while the source is moving outside a patient's body. Moreover acryl board is useful for protecting beta ray from the radioactive source.

\subsection{Radiation protection in phase : C}

The shield effect of a lead apron of 0.25 $\mathrm{mmPb}$ equivalent protector over the braking radiation penetrating from the patient is about $45 \%$ (the scattering dose of conventional X-ray technique is about $90 \%$ ). The energy of the braking radiation was higher than that of a conventional X-ray room. Braking radiation with energy of about $860 \mathrm{keV}$ was detected. However, the dose in the work area was low compared with other medical X-ray procedures. The cardiologist who performs PCI including intracoronary radiotherapy with ${ }^{32} \mathrm{P}$ has to consider the patient's condition. It is important that the staff stand near the patient in emergency care. Moreover, it is important for the mental relief of a patient that the cardiologist can be near the patient.

\section{Conclusion}

The interventional cardiologists experienced less exposure dose during intracoronary radiotherapy with ${ }^{32} \mathrm{P}$ compared with the conventional X-ray technique. The exposure dose was $2.0 \mu \mathrm{Sv} /$ procedure as an effective dose in average irradiation time. The interventional cardiologist is exposed mainly when a radioactive source is outside a patient [H' $\left(10,0^{\circ}\right): 1.0 \mu \mathrm{Sv}$ and $\left.\mathrm{H}^{\prime}\left(0.07,0^{\circ}\right): 100 \mu \mathrm{Sv}\right]$. The exposure dose can be reduced by increasing the distance against a moving radioactive source outside the patient. Moreover, the acryl board was useful for protecting against beta ray from the radioactive source. This investigation indicates that intracoronary radiotherapy with ${ }^{32} \mathrm{P}$ has a higher degree of radiation safety than treatment using a gamma ray source.

\section{Ackmowledgements}

The authors are much indebted to Koichi Kuromi, Guidant Vascular Intervention, Kazuki Matsumoto, Chiyoda Technol Corporation and Atsuhiko Togashi, Niigata University for the collaboration and their technical advice.

\section{Reference}

1) Pocock, S. J., Henderson, R. A., Rickards, A. F., Hampton, J. R., King, S. B. $3^{\text {rd }}$ Hamm, C. W., Puel, 
J., Hueb, W., Goy, J. J. and Rodriguez, A. : Metaanalysis of randomised trials comparing coronary angioplasty with bypass surgery, Lancet, 346, 1184-1189(1995)

2) Waksman, R., Raizner, A. E., Yeung, A. C., Lansky, A. J. and Vandertie, L. : Use of localised intracoronary beta radiation in treatment of instent restenosis : the INHIBIT randomised controlled trial, Lancet, 359, 551-557 (2002)

3) Raizner, A. E., Oesterle, S. N., Waksman, R., Serruys, P. W., Colombo, A., Lim, Y. L., Yeung, A. C., van der Giessen, W. J., Vandertie, L., Chiu, J. K., White, L. R., Fitzgerald, P. J., Kaluza, G. L. and Ali,
N. M. : Inhibition of restenosis with beta-emitting radiotherapy : Report of the Proliferation Reduction with Vascular Energy Trial(PREVENT), Circulation, 102, 951-958(2000)

4) Balter, S., Oetgen, M., Hill, A., Sacher, A., Lipsztein, R., Collins, M. and Moses, J. : Personnel exposure during gamma endovascular brachytherapy, Health Phys., 79, 136-46 (2000)

5) Nelson, W. R., Hirayama, H. and Rogers, D. W. O. : The EGS 4 Code system, SLAC-265(1985)

6) ICRU REPORT 56 : Dosimetry of external beta rays for radiation protection, 107-109 (1997)

要旨

\title{
32P を用いた冠状動脈血管内放射線治療における従事者被曝
}

\author{
福田篤志，北林啓太郎，岩舘美晴，山口一郎* \\ 滋賀県立成人病センター放射線部 \\ 524-8524 滋賀県守山市守山 5-4-30 \\ *国立保健医療科学院生活環境部 \\ 108-8638 東京都港区白金台 4-6-1
}

冠状動脈疾患の治療法として $32 \mathrm{P}$ を用いた血管内放射線治療が注目されている。この治療を安全 に行うには, 術者の被曝線量を推計する必要がある。そこで、患者体外の線源移送中においては $70 \mu \mathrm{m}$ 線量当量により術者への $\beta$ 線被曝を推計した。また線源挿入後は, $1 \mathrm{~cm}$ 線量当量を用いて 制動放射線に対する術者被曝を推計した。

その結果, 本治療法における 1 回あたりの術者の $1 \mathrm{~cm}$ 線量当量は $2 \mu \mathrm{Sv}$ であり，通常の X 線を 用いた検査や治療に比べて少なかった。しかし，患者の体外を移送中 (7 秒間) の線源からは $70 \mu \mathrm{m}$ 線量当量率で $100 \mu \mathrm{Sv} 7$ 秒間と比較的高線量率の $\beta$ 線被曝があるため, 線源から距離をおくか遮 蔽を考慮すべきであると考えられた。 